\title{
Low- $P$ metamorphism following a Barrovian-type evolution. Complex tectonic controls for a common transition, as deduced in the Mondoñedo thrust sheet (NW Iberian Massif)
}

\author{
Ricardo Arenas ${ }^{\mathrm{a}, *}$, José R. Martínez Catalán ${ }^{\mathrm{b}, 1}$ \\ a Departamento de Petrología y Geoquímica, Facultad de Geología, Universidad Complutense, 28040 Madrid, Spain \\ ${ }^{\mathrm{b}}$ Departamento de Geología, Universidad de Salamanca, 37008 Salamanca, Spain
}

\begin{abstract}
The Mondoñedo thrust sheet has been studied to investigate the complex dynamic relationships that may be involved in the development of low- and medium- $P$ metamorphic domains. This unit underwent an initial medium- $P$ event during the initial stages of Variscan convergence, related to crustal thickening. Subsequently, the thrust sheet evolved to a low- $P$ baric type of metamorphism, related to syn-convergence thinning and exhumation. Its footwall, cropping out in two tectonic windows, registered a different evolution, with a low- $P$ history that evolved from low- to high- $T$ under a high geothermal gradient. Several different $P-T$ paths of the Mondoñedo thrust sheet and its relative autochthon are traced and interpreted according to the structural evolution of the area. Following the initial crustal thickening, two main syn-convergence extensional shear zones developed. One of them occurs in the hangingwall, whereas the other affects the footwall unit. Both extensional shear zones were contemporaneous with ductile thrusting in the inner parts of the thrust sheet, and their activity is viewed as a consequence of the need for gravitational re-equilibration within the orogenic wedge.

The most commonly accepted models of tectonothermal evolution in regions of thickened continental crust assume that low- $P$ metamorphism is essentially a late phenomenon, and is linked to late-orogenic tectonic activity. In the Mondoñedo thrust sheet, our conclusions indicate that low- $P$ metamorphism may also develop during convergence, and that this may occur in at least two cases. One is tectonic denudation of an allochthonous unit during its emplacement, and the other, thinning and extension at the footwall unit of an advancing thrust sheet. As a consequence, the low- $P$ evolution may show different characteristics in different units of an orogenic nappe pile.
\end{abstract}

Keywords: Variscan metamorphism; Barrovian to low-P evolution; NW Iberian Massif

\footnotetext{
* Corresponding author. Tel.: +34-91-3944908; fax: +34-915442535 .

E-mail addresses: arenas@geo.ucm.es (R. Arenas), jrmc@usal.es (J.R. Martínez Catalán).

${ }^{1}$ Tel.: +34-923-294488; fax: +34-923-294514.
}

\section{Introduction}

Thermal models of orogenic regions characterized by crustal thickening have shown that their thermal evolution follows rather systematic patterns. For intermediate values of the more common parameters intervening in the thermal history, mesocrustal domains 

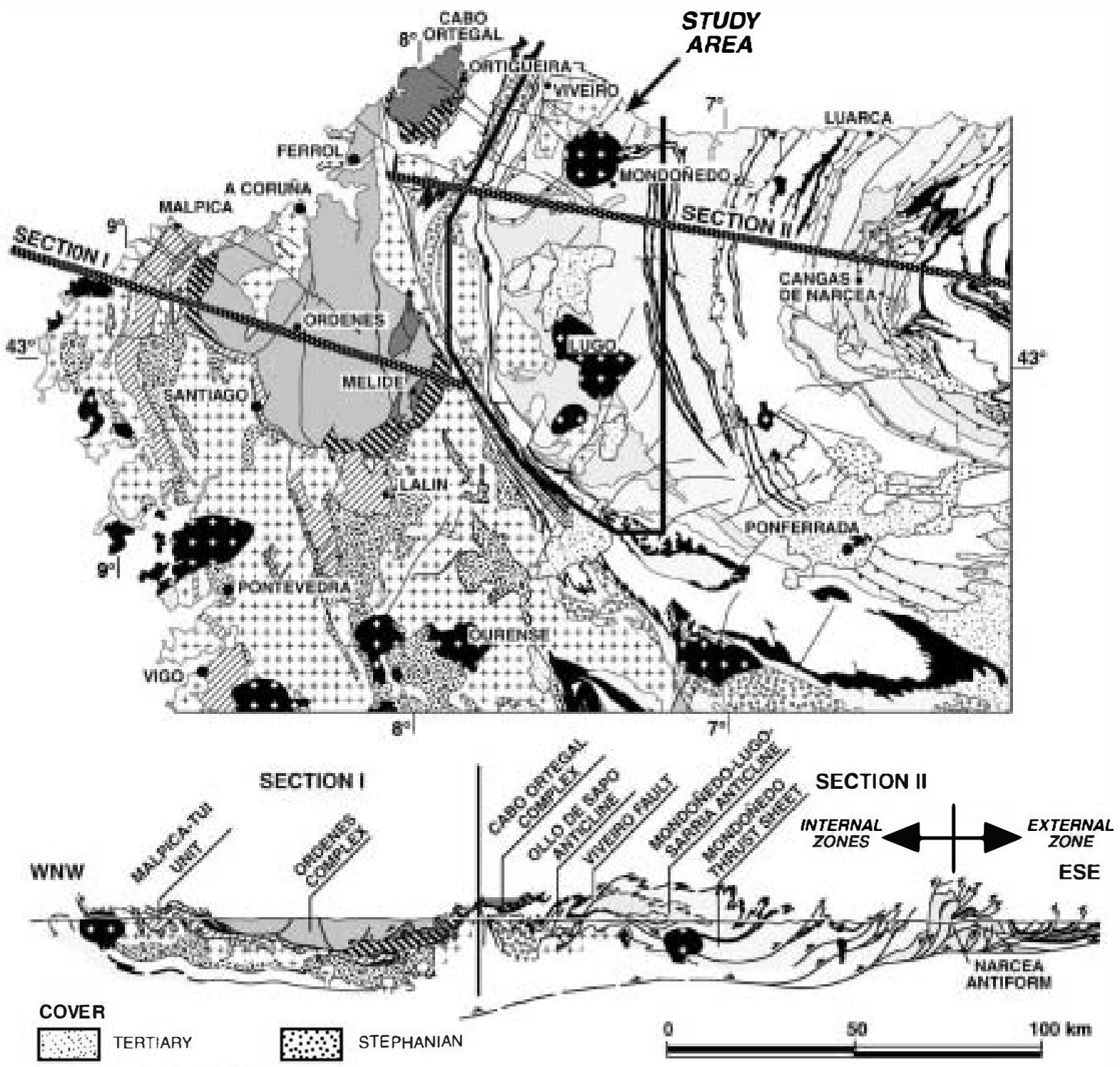

VARISCAN GRANITOIDS

$\because$ POST-KINEMATIC +t++ SYN-KINEMATIC

ALLOCHTHONOUS COMPLEXES

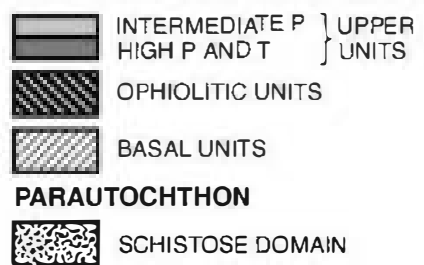

AUTOCHTHON

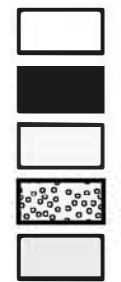

UPPER PALEOZOIC: MIDDLE ORDOVICIAN TO LOWER CARBONIFEROUS ARMORICAN QUARTZITE (LOWER ORDOVICIAN) LOWER PALEOZOIC: CAMBRIAN TO LOWER ORDOVICIAN pre-variscan orthogneisses UPPER PROTEROZOIC

Fig. 1. Geological map and cross section of the NW Iberian Massif, with location of the study area. 
underg• a medium-pressure metamerphic ev•lution (England and Thompson, 1984). In fact, this Barr-vian-type evelution has been considered an indicative for collision tectonics (Thompson and England, 1984). However, for most middle and lower crustal levels, the medium- $P$ metamorphic history follows from a previous one of high- $P$ roughly synchronous with the maximum burial. Nevertheless, because of the inferred clockwise shape of the $P-T-t$ paths developed in the medium to higher $P$ parts of the belt, evidence for the early maximum $P$ segment $\bullet$ f the $P-T-t$ path is usually -bliterated by the subsequent recrystallization at peak $T$, specially when the $P-T$ path reach a high- $T$ thermal peak.

Numerical experiments show that most of the $P-T$ paths inside a thickened crust tend to approach the low- $P$ metamorphic field after the thermal peak and during strong decompression. When exhumation is only due to erosion, England and Thompson (1984) have suggested that the low- $P$ field is not reached by the commøn $P-T$ paths. But, as a late event $\bullet$ l løw- $P$ is the norm rather than the exception in collisional orøenic belts, one has to conclude that erosion is not the only process responsible for the low- $P$ metamorphic gradients. Abundant magmatism may help the trajectories to enter the low- $P$ domain of the $P-T$ space, but late-øregenic extension has als been claimed to explain broad regions with low- $P$ metamørphism (England, 1987; Thømpsøn and Ridley, 1987). Many regional contributions have described the quick exhumation of deep crustal sectors in the footwall of large extensional detachments (Sandiford, 1989; Platt, 1993; Ruppel, 1995). These sectors appear nowadays as dome-shaped, low- $P$ pluton $\bullet-m e t a m \bullet r-$ phic complexes (Dewey, 1988; Reinhardt and Kleeman, 1994; Escuder Viruete et al., 1994, 2000). Bıth pluton-metamorphism and extension are the mechanisms most commonly used to explain the low- $P$ metamorphism in collisional belts.

This contribution presents a study carried out in the Mondøñede thrust sheet and its authechthon, in the NW of the Iberian Massif (Fig. 1), which forms part of the Variscan $\bullet$ renenic belt. Our results indicate that regional low- $P$ metamorphism develop in sectors of collisional orøgenic wedges that register a rich and complex structural evolution. The løw- $P$ event -ccurred there both in the hangingwall and the footwall -f a huge contractional structure. In the thrust sheet it- self, the løw- $P$ metamorphism took place after a medium- $P$ event clearly related to crustal thickening, but in the footwall, the low- $P$ metamorphism is the only significant event of recrystallization. Moreover, the complex structural and metamorphic relationships established between the upper and lower blocks of the Mondoñede thrust fault give insights inte the evolution of the Variscan oregenic wedge with time. Histories like the one described here may be relatively commøn in orøenic belts, though could they have been remained unnoticed in many cases.

\section{Geological setting}

A first deformation episode of recumbent folding with $\mathrm{E}$ vergence characterizes the Variscan orøgeny in the intemal parts of the NW Iberian Massif. This was followed by ductile and brittle thrusting toward the E, and subsequent open steep folding (Fig. 1).

The Mondoñedo nappe is a large crystalline thrust sheet, formed essentially by low to high-grade metasediments ranging in age from Upper Proterøzıic to Lower Devonian. Metapelites are the most common lithølogies, followed by quartzites and, less abundant, carbønates. The thickness of the sedimentary succession varies, reaching at most $6000 \mathrm{~m}$, but due to recumbent folding, its present structural thickness roughly doubles the sedimentary $\bullet$ ne. T• the $\mathrm{W}$, the thrust sheet is bounded by the Viveire fault, a westdipping normal fault cutting across the nappe and its relative autochthon (Figs. 2 and 3). Late folding allowed the present-day preservation from erosion of 10 to $12 \mathrm{~km}$ of the thrust sheet in the core of an open synform.

The structure of the hangingwall unit and the basal ductile shear zone has been described by Bastida and Pulgar (1978), Martínez Catalán (1985), Bastida et al. (1986) and Aller and Bastida (1993). The significance of the Mondoñedo nappe in the structural ev $\bullet$ lution $\bullet$ the Variscan belt of NW Spain is discussed in PérezEstaún et al. (1991).

What makes the nappe a very interesting structure is the fact that it can be studied from its front, that runs aløng 200 km (Marcos, 1973; Pérez-Estaún, 1978), to rather internal areas søme $65 \mathrm{~km}$ to the west, where its relative autochthon is exposed in two tectonic windows, named Xistral and Monte Carballosa (Fig. 2). 


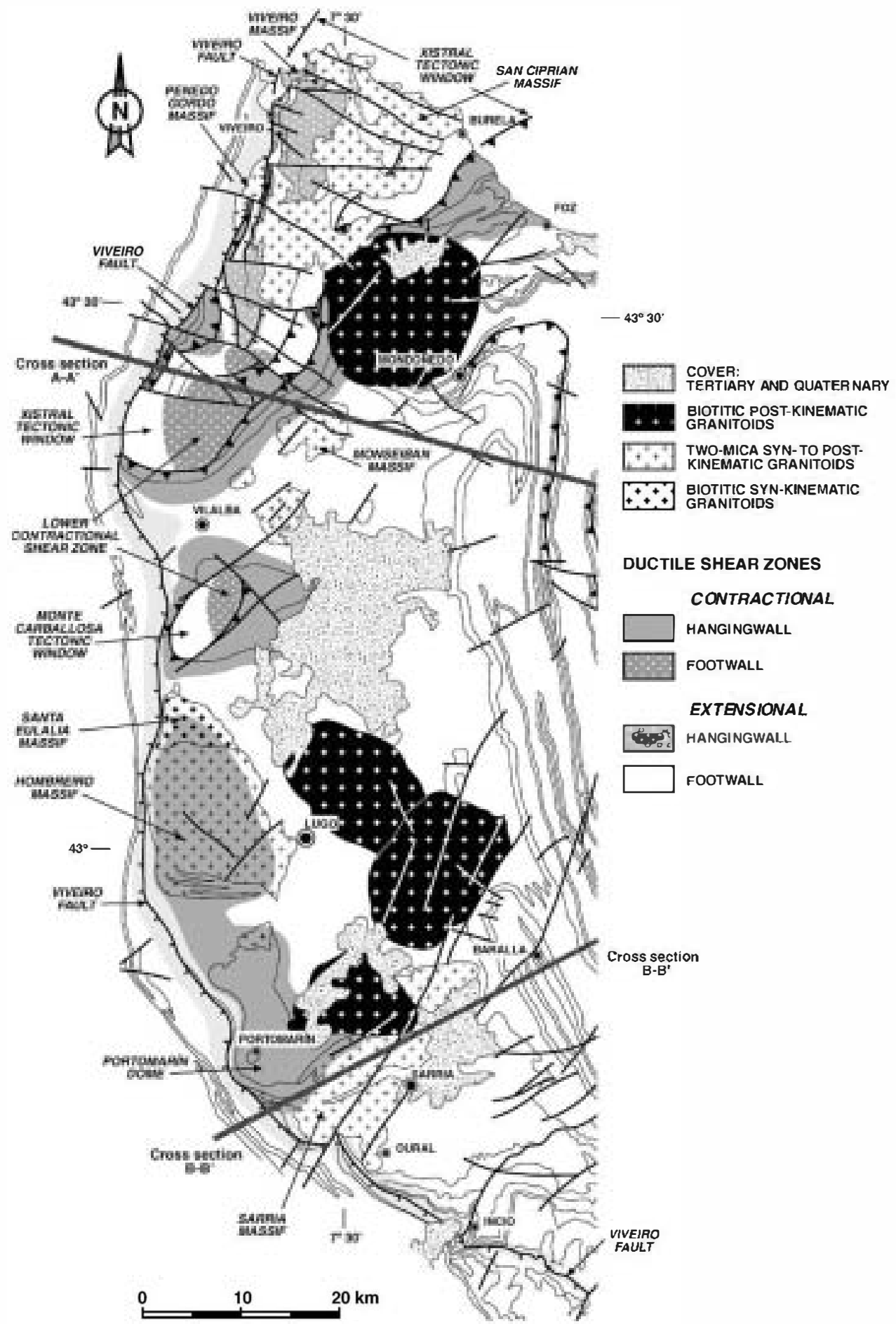

Fig. 2. Map showing the distribution of ductile shear zones in the hangingwall and footwall to the Mondonedo thrust sheet. 
There, the succession is thought to range form Upper Proterøoic to Løwer Cambrian, but the quartzites dominate over the metapelites and metagreywackes. A careful review of the hangingwall unit and new mapping of the footwall unit in the tectonic windows has shown a complex picture of ductile shear zones with different kinematics and partially overlapping in time. The structural evelution will be presented in a companion paper (Martínez Catalán et al., in press), whereas this contribution deals with the metamorphic evolution.

The first study of metamorphism in the nappe and surrounding areas was carried out by Capdevila (1969). It included a map of the metamorphic zones and a systematic description of the mineral assemblages in the metapelites. Though it was later put in an updated regional context by Bastida et al. (1986), Capdevila's contribution remained the only work to appreach the metamorphic evolution at the scale of the whole Mondoñedo nappe. Its main result is that the regional metamorphism was of the low- $P$ intermediate type of Miyashir (1961). Nevertheless, the author describes the løcal appearance of kyanite, with or without coexisting andalusite that he interprete as related to individual fault zones, such as the Viveir fault. The kyanite-bearing metapelites apparently asseciate to this fault have receive the attention of Martinez et al. (1996) and Reche et al. $(1998 \mathrm{a}, \mathrm{b})$. The latter carried out quantitative thermobarømetric estimations in restricted areas of the nappe.

However, the tectonothermal evolution of the nappe and its relative autochthon had not been approached following a modern perspective that would pay attention to the structural evolution of both the hangingwall and footwall units, and that try to interpret the $P-T$ paths in terms of the evolving macrostructures. This is the aim of this contribution, and we will show that the metamorphism depicts a complex evolution that, even reaching high temperatures in both units, followed very different paths. Whereas a typical medium- $P$ metamørphism of Barrøvian affinities characterizes the hangingwall unit, a low- $P$ evolution took place below the Mondoñedo thrust sheet. The model envisaged to explain these differences may be applied to other sectors and orogenic belts where an alternation of medium- and low-pressure metamorphic regimes $\bullet c c u r$.

\section{Synmetamorphic shear zones}

The first structures developed in the study area were large recumbent folds. These folds reflect an episode of crustal shortening and thickening, with the deformation widely distributed and developing a regional cleavage affecting all the metasediments. The associate regiønal metamorphism was $\bullet$ intermediate pressure (Miyashirø, 1961) with kyanite-sillimanite, s• cømmøn in mesøcrustal levels of many orøenic belts (Thompson and England, 1984). The metamorphic zønation, of Barrøvian type, includes chlørite, biøtite, gamet, staur lite-kyanite, sillimanite and sillimaniteorthoclase (Fig. 4). The isøgrads crosscut the recumbent folds (Capdevila, 1969), but they were deformed by the subsequent ductile shear zones, and overprinted by the thrust and normal faults (Fig. 3).

The most important recumbent fold is the Mondo-

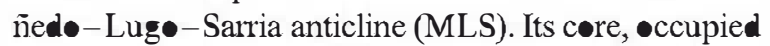
by Upper Proter zoic metapelites and metagreywackes (Fig. 1), has a mean thickness of $6 \mathrm{~km}$ aløng most of the føld, as deduce from crøss sections constructed by down-plunge projection of the hinges and limbs of the second-order følds. T• the W and SW, however, the normal and reverse limbs progressively approach each -ther, and the fold core becomes less than $1 \mathrm{~km}$ thick (Fig. 3). The thinning of the fold nappe toward its intemal parts is reflected als in the thickness of the Pale zoic formations on both limbs and in the width of the metamorphic zones (Figs. 3 and 4), and is due to the

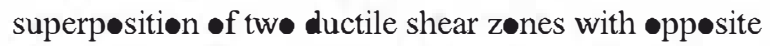
senses $\bullet$ movement.

One is the basal shear zone of the Mondoñedo nappe, a 3-3.5-km-wide zone of ductile deformation with top to the E motion, that $\bullet$ curs at the base of the thrust sheet (Bastida and Pulgar, 1978; Bastida et al., 1986; Aller and Bastida, 1993). This is interpreted as a contractional structure equivalent to a ductile thrust, and it is assumed that the allochthonous sheet moved without much intemal deformation, except at the basal zone and, once it had reached relatively high crustal levels, motion eccurred over a brittle thrust fault.

The other is a low-dipping shear zone with top to the W motion, develope in the upper parts of the MLS anticline (Figs. 2 and 3). This zone of deformation is clearly superimpese to the normal limb of the MLS anticline. It shows an associated subhorizontal crenulation cleavage or a new schistosity, as well as a 


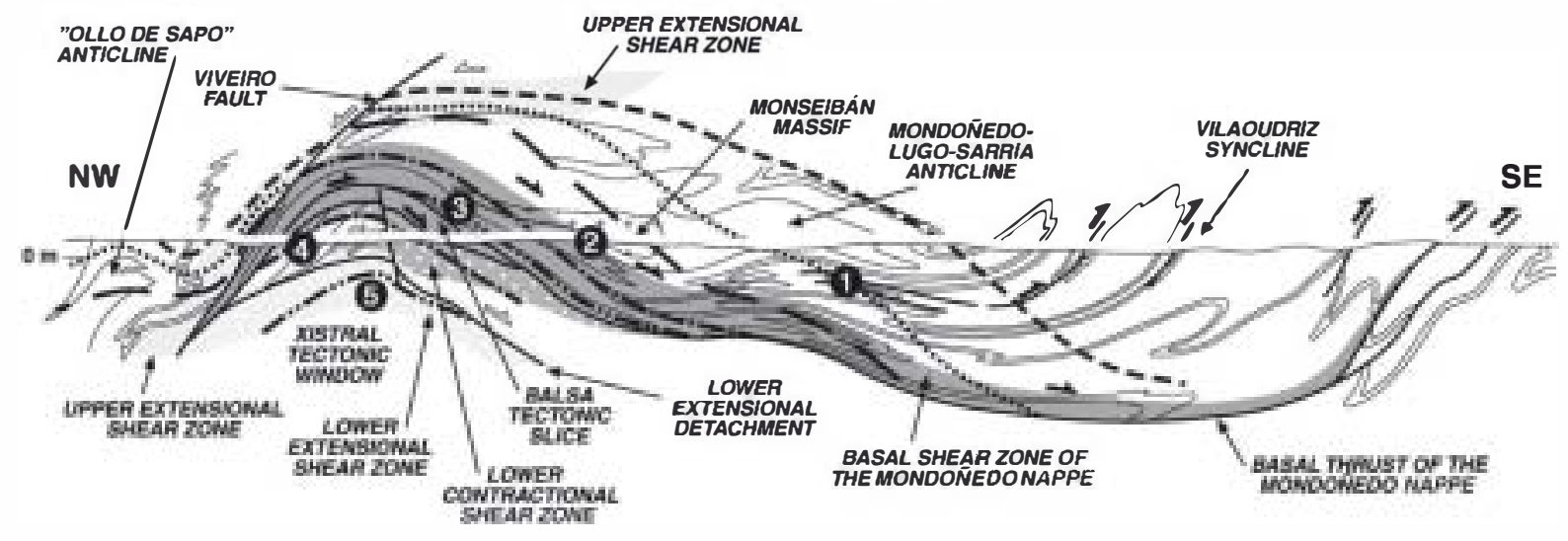

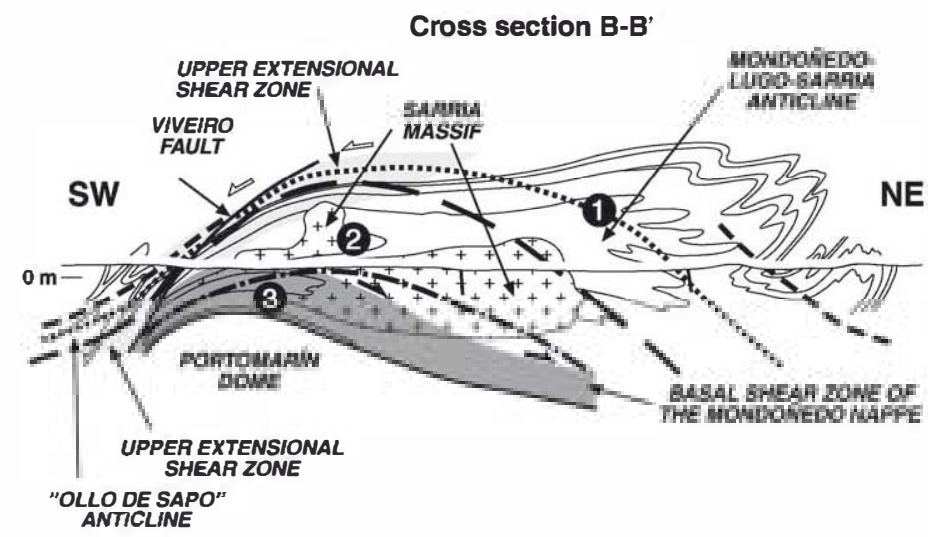

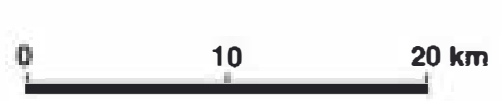

\section{ISOGRADS}

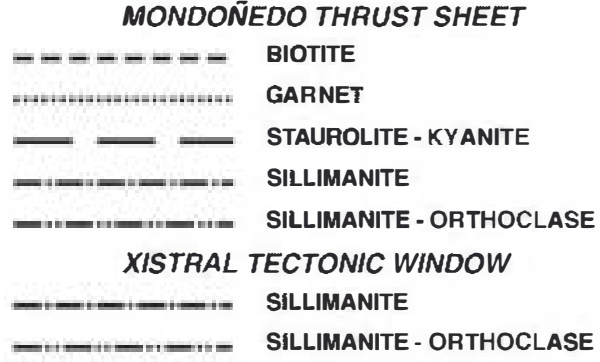

DUCTILE SHEAR ZONES CONTRACTIONAL EXTENSIONAL HANGINGWALL FOOTWALL HANGINGWALL

FOOTWALL

Fig. 3. Two general sections across the Mondoñedo nappe, showing the shear zones and the metamorphic isograds. Arrows show movement of con ractional (black) and extensional (white) shear zones and faults. For location, see Fig. 2 . Numbers 1 to 5 refer to the location of the $\boldsymbol{P}-T$ paths shown in Fig. 9.

mineral lineation striking E-W. Its maximum thickness is estimate in $2 \mathrm{~km}$, and decreases progressively to the $\mathrm{S}$ of Oural (Fig. 2). This shear zone has a subtractive character, as deduced from the thinning of the normal limb and core of the MLS anticline, and als $\bullet$ the metamorphic zones (Fig. 3, section B-B' ), and will be called the upper extensional shear zone.

The tw• shear zones mentioned eccur in the hangingwall to the Mondoñedo thrust fault, but synmetamorphic shear zones have been identified alse at its footwall. Relics of the basal shear zone of the Møndoñed nappe have been preserved in the upper part of the footwall unit (Figs. 2 and 3). In addition, a zone of high strain with kinematic criteria indicating top to the E shearing has been identified in the two tectonic windows. Geometrically, this lower contractional


to the E, implying that prior to late folding, it was more incline to the $\mathrm{W}$ than the Mondeñedo thrust itself. Because its dip was toward the uptbrown block, it is interpreted as a ductile thrust.

However, the most important ductile shear zone occurs in the deep parts of the Xistral tectonic window. A detachment fault underlies a thick quartzitic forma- 
tion and, below, intense shearing affects the underlying schists, paragneisses and migmatites outcropping at the core of the $\bullet$ pen antiform that is at the origin of the tectonic window (Figs. 2 and 3, section A-A'). Shearing shows a top to the $\mathrm{E}$ sense of motion but, in this case, structural criteria suggest that its flow plane had an original dip to the E, i.e., to the downthrown block. Furthermore, a subtractive metamorphic jump that will be described below supports that this is an extensional structure, that will be referred to as the lower extensiønal shear zone. Its upper limit is the lower extensional detachment (Fig. 3, section A-A').

All of the structures described above were active during different stages of nappe emplacement. Later on, the Viveir fault overprinted both the hangingwall and footwall units of the Mondoñedo thrust sheet (Figs. 2 and 3). This is a normal brittle fault dipping $40-60^{\circ} \mathrm{W}$ that als has an asseciate narrow ductile shear zone (n๑t shøwn in the maps and cross sections). Minor recumbent folds with $W$ vergence and weakly curved hinges, and S-C or ECC microstructures (Platt, 1984), indicate a top to the W motion on the fault, with a slight right-lateral component.

\section{Metamorphic zones and isograds}

The regional distribution of metamorphic zones is shown in Figs. 4 and 5. They have been traced through the study of mineral parageneses in significant gelogical sections. A fundamental conclusion is the difference in the metamorphic zonation between the thrust sheet and its relative autochthon. In the former, the evolution is $\bullet$ ne of medium- $P$, essentially Barr $\bullet-$ vian, but with a continuation towards temperatures somewhat higher than those registered in the type area of Scotland (Yardley, 1989). This permits to map the classical Barrovian zones, widely described in the literature. Conversely, in the footwall unit, the evolution is of lower pressure, with a less evident metamorphic zonation that requires a specific selection.

In the hangingwall unit, the mapped zones are, from

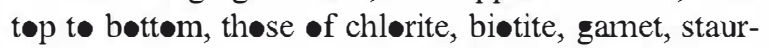
-lite-kyanite, sillimanite and sillimanite-orthøclase. The upper three zones eccur in the central and eastern sectors of the Mondoñedo nappe, and the isegrads separating them show a roughly N-S attitude (Fig. 4). The staurølite-kyanite zone •ccupies most of the western part of the nappe (Figs. 4 and 5). Commonly, in Barrovian terranes, the staur lite and kyanite zones can be separated, the latter being the deeper (Yardley, 1989). However, in the Mondoñedo thrust sheet, cœexistence of both phases $\bullet$ ccurs immediately below the gamet zone. That is, the first staur-lite-bearing schists alsø contain kyanite (tøgether with chloritøid, chlorite, white mica, quartz, plagioclase and ilmenite). This prevents the separation of the twø zones. Prøbably, the quick appearance of kyanite indicates a metamorphic evolution in the higher-pressure domain -f the medium- $P$ metamorphism. T• the $\mathrm{W}$, the metamorphic zonation of the thrust sheet is truncated by the Viveirø fault.

The first sillimanite zone, characterized by schists and paragneisses with sillimanite and muscovite, crøps out in three areas: as a narrow strip to the $\mathrm{E}$ of the


granitic massif and in the Portomarin dome (Figs. 4 and 5). The second sillimanite zone, characterized by migmatitic paragneisses with sillimanite and orthclase withøut primary muscovite, is restricted to an even narrower strip to the $\mathrm{E}$ of the Xistral tectonic window. These paragneisses represent the highest metamorphic grade identified in the area; n॰ ๑utcrøpping rocks ever reached the sillimanite-cordieriteorthøclase $\bullet$ higher temperature zønes.

The metamorphic succession of the footwall unit developed under lower baric conditions. In similar domains, a generally accepted model for the metamorphic zonation is lacking, and different zones have been describe in different regiøns (Miyashire, 1961; Harte and Hudsen, 1979; Yardley, 1989). Consequently, we must first consider what zones can be mapped. Beginning from the deepest parts, in the core of the Xistral tectonic window, paragneisses without primary muscovite and clear evidence of partial melting can be ascribed to the sillimanite-orthøclase zone (Fig. 5). Above, the paragneisses and schists are characterized by sillimanite and syntectonic primary muscovite, withøut assøciated partial melting, sø that they must represent the first sillimanite zone.

More problematic is the zonation of the overlying levels, corresponding to the intermediate temperatures. For similar metamorphic conditions, it is common the separation of the cordierite and andalusite zones (Harte and Hudson, 1979), the first being of lower temperature. However, in our case, the medium- $T$ metasedi- 




Fig. 4. Map of metamorphic zones and isograds in the Mondoñedo thrust sheet and its footwall unit. 


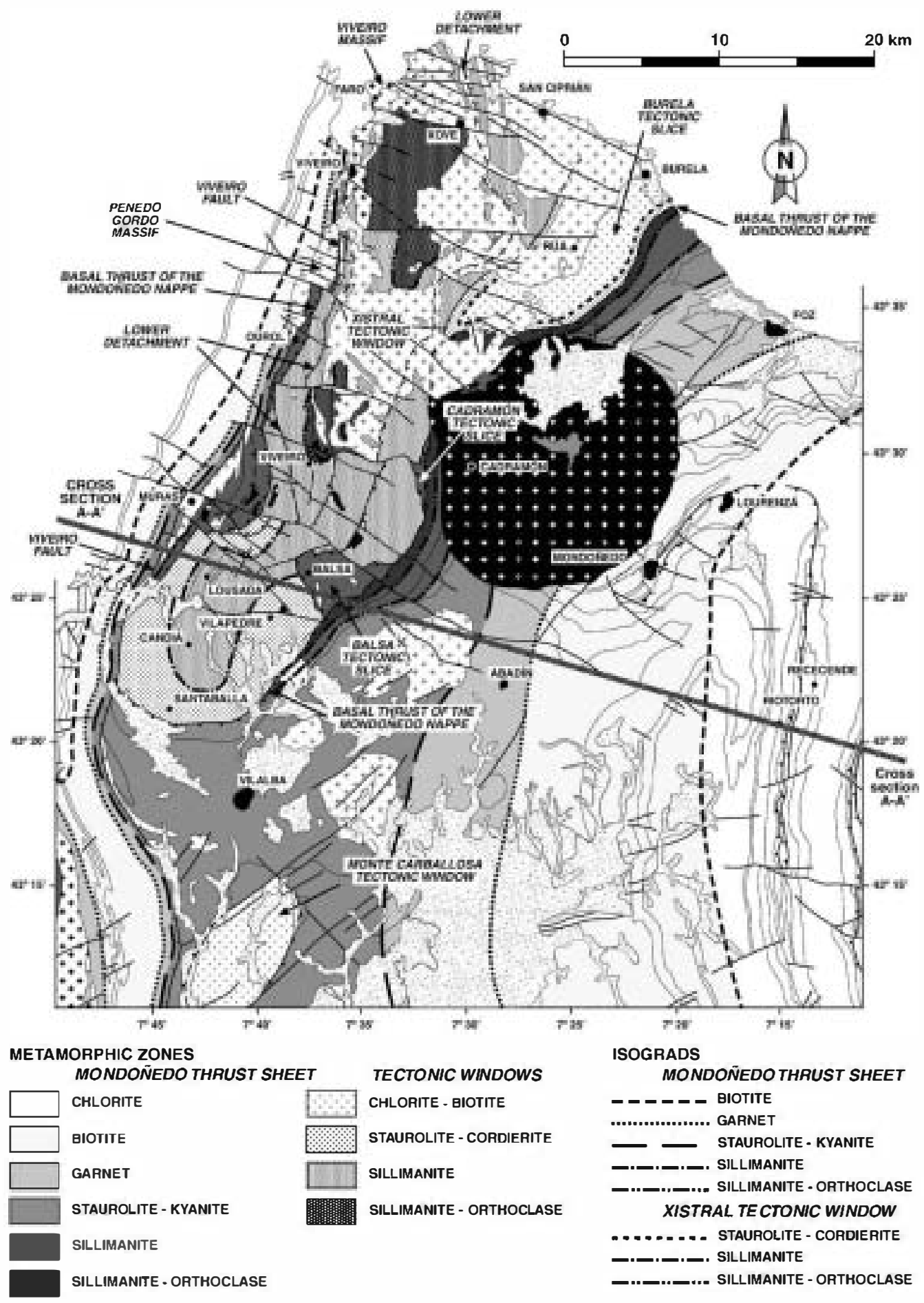

Fig. 5. Detailed map of metamorphic zones and isograds in the tectonic windows and surnounding parts of the Mondonedo thrust sheet. 


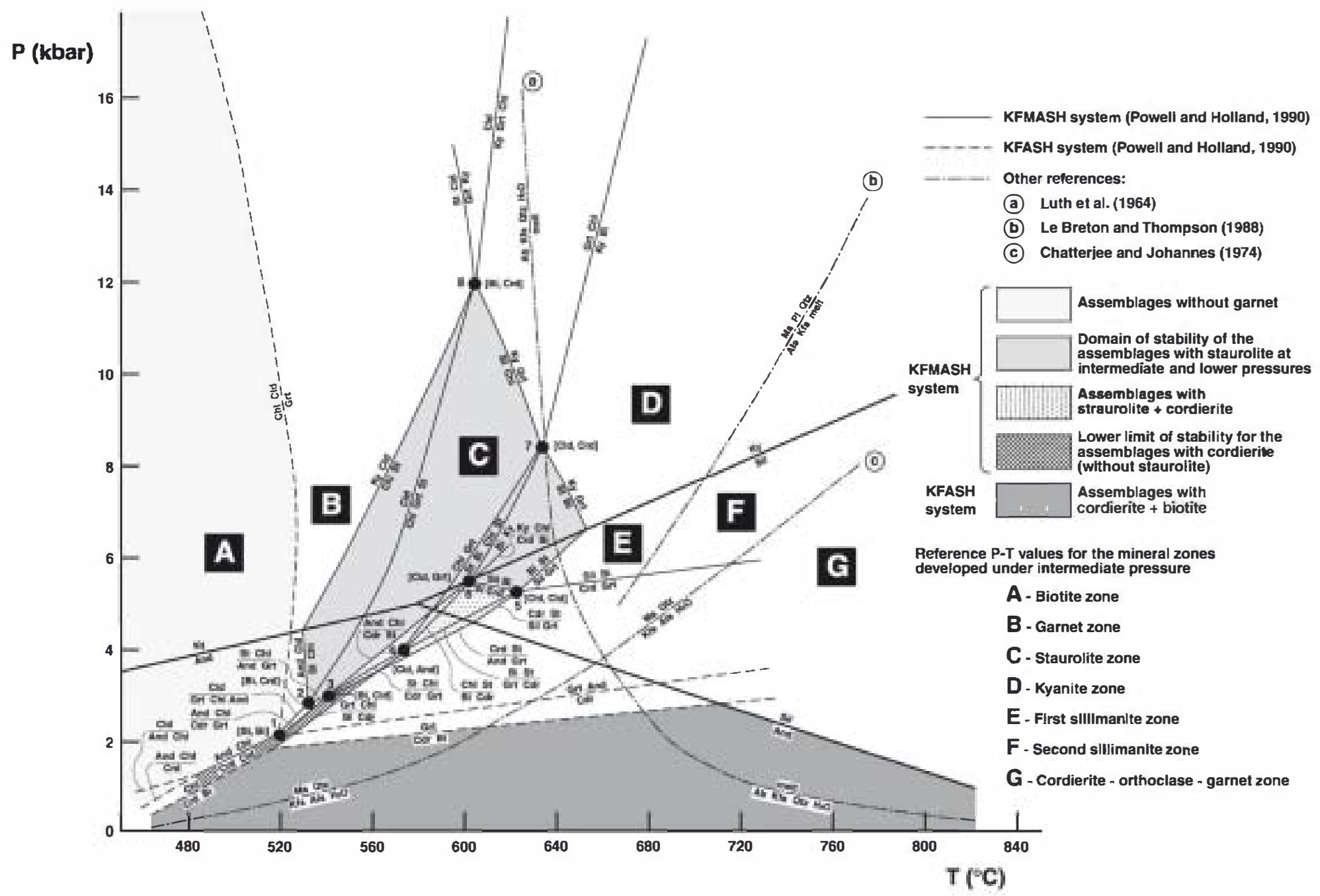

Fig. 6. Perogenetic grid for metapelites used to constrain the metamorphic evolution of the Mondoñedo thrust sheet and its footwall unit. The grid includes a collection of significative reactions in the KFMASH and KFASH systems (Powell and Holland, 1990), as well as other important equilibria in metapelites (Luth et al., 1964; Chatterjee and Johannes, 1974; Le Breton and Thompson, 1988). Some significant stability domains and reference $\boldsymbol{P}-T$ conditions for the characteristic mineral zones of the intermediate- $\boldsymbol{P}$ metamorphism are also shown. 
ments of the footwall unit may contain staurølite in addition to cordierite, and the andalusite is not common at all. For this reasøn, a single staur zone has been defined

by the petrogenetic grid of Powell and Holland (1990) for metapelites that shows the possible coexistence of staur lite and cordierite at low pressures. This petrogenetic grid will be used to discuss the $P-T$ paths of both the hangingwall and footwall units (Fig. 6).

Løw- $T$ metasediments characterize the whøle Monte Carballosa tectonic window and alsø occur to the $\mathrm{S}$ and SW of Burela, in a tectonic slice in the NE part of the Xistral tectonic window (Fig. 5). The røcks there are mostly quartzites, which evidently does not help to establish a detailed metamorphic zonation. For that reasøn, and considering their mineral assemblage, they have been ascribed to a chlørite-biotite zone.

\section{5. $P-T$ paths}

One of the main tools to analyse the metamorphic evolution of a complex area are the $P-T$ paths followed by the most significant

a marked dependence of the dynamic history of each


Thompson and England, 1984; Davy and Gillet, 1986; England, 1987; Thompson and Ridley, 1987). After a careful petrographic analysis, tw• techniques can be used to establish the $P-T$ paths. One is the use of geothermometers and gebarometers applied to mineral assemblages in equilibrium, formed along successive stages. The ther uses petrogenetic grids to analyse the reactional space where the actual parageneses are stable.

By using thermobarometry, individual paths can be trace with precision (Arenas et al., 1995, 1997; Escuder Viruete et al., 1997, 2000), but this is a very slow task when one has to interpret a wide region and just wants to catch the essential features of its tectonothermal evolution. The altemative approach will be applied here, using a petrogenetic grid which, in any case, permits to compare rather accurately the temperatures, though is somewhat less precise for the pressures, mainly inside the stability domain of kyanite $\bullet$ the high- $T$ part of sillimanite.

We have used the petrogenetic grid of Powell and Hølland (1990) for the pelitic system (KFMASH), adding several reactions of the system KFASH -btaine by the same authors, and the curves of Luth et al. (1964), Le Bretøn and Thompsøn (1988) and Chatterjee and Johannes (1974), for the minimum melting in the hydrous granitic system, and for the disappearance of muscovite (Fig. 6). Alsø, several domains $\bullet$ mineral stability meaningful for the Mondoñedo

$P-T$ reference conditions for mineral zones typical of medium- $P$ metamorphism. Independently of the accuracy in the establishment of the $P$ and $T$ conditions, the grid of Powell and Hølland (1990) may be used as a tool for comparisøn, because of its internal coherency, -btained by rigorøus thermodynamic calculations in the system of reference. In order to establish comparisøns, this grid is a better tool than a group of reactions deduced from experiments carried out with different initial compositions.

In the rest $\bullet$ this chapter, the $P-T$ paths $\bullet$ the most significant

\section{doñede}

tion is based on a detailed petrographic study of these lithologies, together with the interpretation of the tectonic fabrics (foliations and lineations) and their relationships with the macrostructures.

\section{1. $P-T$ paths in the hangingwall unit}

The upper parts of the Mondoñedo

characterized by the zones of chlorite, biotite and gamet. Considering the mineral assemblages of the tw- latter zones, and assuming a geothermal gradient of $2{ }^{\circ} \mathrm{C} / \mathrm{l}$ during burial, two approximate $P-T$ paths have been traced taking int account the reaction $\mathrm{Chl}+\mathrm{Cld}=\mathrm{Grt}(\mathrm{KFASH}$ system, Fig. 7, paths $\mathrm{A}$ and B).

More detail can be obtained for the metamorphic evolution $\bullet$ the schists on the normal limb of the MLS anticline to the W of Vilalba and farther to the S, around Inciv (Fig. 4). These schists •ccupy the upper part of the staur-lite-kyanite zøne, and may be divided in tw main types, according to the presence or absence of kyanite. The latter have a higher Fecontent, and their paragenesis includes muscovite, biotite or chlorit॰id, chlørite, quartz, plagiøclase, garnet, staur lite and ilmenite. Temporary relationships among chloritoid, gamet and staurolite show a typical Barrovian reactional history. 




Fig. 7. $\boldsymbol{P}-T$ paths deduced for the different stuctural levels of the Mondoñedo thrust sheet. 
The kyanite-bearing schists developed from Al-rich compositions, als relatively rich in $\mathrm{Mg}$. Their paragenesis includes muscovite, chlorite, quartz, plagiclase, kyanite, staurelite, chloritoid and ilmenite, but biotite and gamet are absent. This assemblage suggests that the univariant reaction $\mathrm{Ky}+\mathrm{Cld}=\mathrm{Chl}+\mathrm{St}$ (KFMASH system) resulte in a stable asseciation in equilibrium with chlorite + chloritøid + kyanite + staur-lite. Considering that the slightly late character of the staur lite could imply that the equilibrium of the reaction was finally exceeded,

traced to the right of the reaction curve (Fig. 7, path C). The pressure is rather imprecise in this path, due to the lack of reactions giving baric information in the kyanite field for

path, we have used the same thermal gradient as for the gamet and biotite zones, but clearly, the pressure peak must be considere as a lower limit. In any case, the systematic absence of garnet in the assemblages with kyanite would place the baric peak below the invariant pøint 8 (Figs. 6 and 7). This path underwent exhumation through temperatures lower than those of its baric peak, given the lack of significant

asseciated to decompression.

For intermediate sectors of the staur lite-kyanite zøne, the common assøciation contains biøtite, gamet,

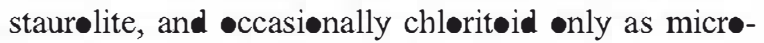
inclusions in gamet. Furthermore, andalusite is commøn as late-kinematic porphyroblasts. These are typical schists $\bullet$ the staur lite (॰r staur lite-kyanite) zøne, that previøusly prograded through chloritøid and garnet and subsequently were decompressed and chilled syn-kinematically through the andalusite field. Consequently, the $P-T$ path (D in Fig. 7) has been traced in the medium $P$ and $T$ domain of the staurelite stability, at higher $T$ than the stability limit of chloritoid (equilibrium Cld $=\mathrm{Chl}+\mathrm{Grt}+\mathrm{St}$ ) and entering the andalusite field

Probably, the retrograde path was always above the invariant point 2 , considering the absence of cordierite. On the other hand, the rocks of the staur lite-kyanite zone never exceeded significantly

the triple pøint of the Al-silicate pølymorphs, because of the absence of sillimanite during decompression. In that way, they probably never exceeded the equilibrium $\mathrm{Chl}+\mathrm{Grt}=\mathrm{Bi}+\mathrm{St}$.

Deeper in the nappe structure, the schists of the first sillimanite zone to the $\mathrm{E}$ of the Xistral tectonic window
(Fig. 5) contain a syn-kinematic assemblage with gamet, staurelite, biotite and sillimanite, followed by andalusite porphyroblasts (up to $15 \mathrm{~cm}$ long, and parallel to the stretching lineation). The $P-T$ path (E in Fig. 7) can be traced very precisely showing a strong decompression and intersecting the equilibria $\mathrm{Chl}+$ $\mathrm{Grt}=\mathrm{Bi}+\mathrm{St}$ and $\mathrm{Bi}+\mathrm{St}=\mathrm{Sil}+\mathrm{Grt}$, to finally

the andalusite stability field.

traced for the schists and paragneisses of the first sillimanite zone in the Portomarín dome (Fig. 4). These røcks may contain syn-kinematic biotite, gamet, staur$\bullet$ lite, kyanite and sillimanite, and late-kinematic andalusite, s- that it is quite possible that their $P-T$ path followed higher temperatures than the equilibria $\mathrm{Grt}+\mathrm{Chl}=\mathrm{Ky}+\mathrm{Bi}, \mathrm{St}+\mathrm{Bi}=\mathrm{Ky}+\mathrm{Grt}$, and $\mathrm{Bi}+\mathrm{St}=$ Sil+ Grt (Fig. 7, path F).

The second sillimanite zone was reached at the base of the thrust sheet to the $\mathrm{E}$ of the Xistral tectonic window (Fig. 5). The rocks are migmatitic paragneisses that may include quartz, plagioclase, biotite, gamet, staurølite, orthøclase, sillimanite and andalusite. However, the most recrystallized, biotite-pøor anhydrous rocks contain quartz, plagiøclase, sillimanite and orthoclase in the assemblage representing the thermal peak. The $P-T$ path shows a strong decompression through the sillimanite stability field, the curves of disappearance of muscovite and finally loosing temperature through the andalusite domain (Fig. 7, path G1). This path may be continued to lower temperatures studying the phyllonites adjacent to the basal thrust fault at the coastal section, SE of Burela (Fig. 5). The phyllønites resulted from exhumation and chilling of the migmatitic paragneisses during thrusting. Thermobaric estimations carried out in these fault rocks (Dallmeyer et al., 1997) suggest conditions of less than $5 \mathrm{kbar}$ (maximum content of $\mathrm{Si}$ in white mica $\left.=\mathrm{Si}_{3.18}\right)$ and temperature around $500 \pm 30{ }^{\circ} \mathrm{C}$ (plagioclase-muscovite equilibrium) for the end of the process (Fig. 7, path G2).

T॰ the $\mathrm{E} \bullet$ f the Xistral tectonic window, a couple $\bullet$ imbricates occurs between the Mondoñedo sheet, and its footwall unit, the Balsa and Cadramón tectonic slices (Figs. 5 and 3, section $\mathrm{A}-\mathrm{A}^{\prime}$ ). Both their stratigraphy and metamorphic evelution indicate that they are fragments detached from the thrust sheet during its emplacement. They clearly belong to the first sillimanite zone, but their $P-T$ conditions were sømewhat intermediate between the basal migmatites 
and the paragneisses of the Portomarín dome (Fig. 7, path $\mathrm{H}$ ).

\section{2. $P-T$ paths in the footwall unit}

In the footwall to the Mondoñedo

lowest $P-T$ conditions are those of the chlorite-biotite zone, preserved in the Burela tectonic slice and the Monte Carballosa tectonic window (Fig. 5). This and the underlying staurelite-cordierite zone are hard to trace with precision because they eccur in an area dominated by quartzites. In Burela, only chlorite and white mica occur in the rare semipelites, but in Monte Carballøsa, post-kinematic biøtite porphyrøblasts sug- gests a somewhat higher grade. The $P-T$ path representing the evolution of both areas is shown in Fig. 8 (path I).

Around Vilapedre, to the $\mathrm{S}$ of the Xistral tectonic window (Fig. 5), the schists of the staur lite-cordierite zone contain quartz, plagioclase, white mica, chlorite, biotite and cordierite. Cordierite appears as late- to post-kinematic pørphyroblasts and their $\bullet c c u r-$ rence indicates a pronounced heating during final stages of the development of the regional foliation (Fig. 8, path J).

In the upper parts of the footwall unit, the general absence of gamet (just one sample with possible weathered gamets) makes the drawing of paths I and

I Burela slice and Monte Carballose tectonic window (chlorite-biotite zone)

J Vilapedre (staurolite - cordierhe zone)

R Lousada (upper part of the first sillimanhte zone)

L Paragneisees to the $\mathbf{S}$ of Viveiró (lower part of the first sillimanite zone)

M Migmatites to the SE of Viveiro and to the $\mathrm{N}$ of Viveiró (second sillimanite zone or sillimanite - orthoclase zone)



Fig. 8. $\boldsymbol{P}-T$ paths deduced for the different stuctural levels of the footwall unit. 
J uncertain. Strictly, both arrows should be traced below the invariant pøint 1 , where the mineral assemblage includes gamet. However, the pressures would then be sø low that are incompatible with the structural data. A thickness of at least $10 \mathrm{~km}$ is preserved today in the central parts of the Mondoñedo

and some erosion must be expected since the Carboniferous. This is incompatible with the approximately 8 $\mathrm{km}$ corresponding to the $2 \mathrm{kbar}$ of invariant point 1 . The absence of garnet may have a compositional explanation but anyway, the maximum pressure sustained by these rocks should have been low.

The schists of the upper part of the first sillimanite zone around Lousada (Fig. 5) may contain biotite, staurølite, cordierite, sillimanite, søme gamet and primary muscovite. The cordierite grew later than gamet and staurølite. Still later growth of sillimanite represents the bighest temperature reached in the area. The arrow has been traced crossing the stability fields assemblages with staurølite and staurølite + cordierite, reaching finally

the curve of partial melting (Fig. 8, path $\mathrm{K}$ ). It is possible that these schists developed an assemblage with gamet + staur lite + biotite + chlorite + cordierite during their evolution. Then, the $P-T$ path would pass through the invariant pøint 4 . Some cordierite porphyroblasts are syn-kinematic, but the largest are postkinematic, sø that their growth may be linked the final

with a slight decompression, following a $P-T$ path that did not reach the curve of disappearance of muscovite.

The lower part of the first sillimanite zone can be studied to the $\mathrm{S}$ of Viveiro, in the centre of the Xistral tectonic window (not to be confused with Viveirø, to the $\mathrm{N}$ and in the coast, that gives its name to the Viveir fault; see Fig. 5). The røcks are paragneisses with sillimanite, biøtite and primary muscovite, but their strong recrystallization has everprinte any trace -f early phases of their thermal history. Gamet has never been found in these rocks, which hinders the precise tracing of their $P-T$ path. In any case, the evolution is one of low pressure, and has been drawn parallel to that of the schists arøund Løusada but entering somewhat more inside the stability field sillimanite (Fig. 8, path L). The absence of partial melting and the systematic eccurrence of primary muscovite limit the progradation of this path into the sillimanite field.
The migmatites eccurring to the E of Viveirø and

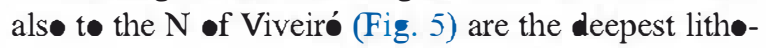
logies outcropping in the footwall unit. Their mineral assemblage was developed during the thermal peak, and n๑ previous mineral phases have been preserved. They contain sillimanite, biøtite, $\bullet$ rthøclase and, ๑ccasiønally, gamet. Partial melting is widespread and all the white mica is secondary. The final progradation of the $P-T$ path has been traced inside the sillimanite field,

disappearance of muscovite (Fig. 8, path M). F•r earlier stages, the path cannot be established due to the practical absence of pre-peak phases. It is doubtful if the arrow went below the triple point of Al-silicate polymorphs or along the stability field

existence of the lower extensional shear zone and an asseciated detachment (Fig. 3, section A-A') suggests a structural thickness above the migmatites more important before the beginning of extension. This supports the tracing of the $P-T$ path $\mathrm{M}$ above that of path L (Fig. 8) and, consequently, arøund the triple pøint. The absence $\bullet$ kyanite and the scarcity $\bullet$ gamet suggests that, in any case, the pressures were not too high.

\section{Interpretation of the $P-T$ paths}

A synthesis of the $P-T$ evolution of the study area is shown in Fig. 9. Paths 1, 2 and 3 correspond to the upper, middle and lower parts of the Mondoñedo sheet and paths 4 and 5 to its relative autechthon, above and below the lower extensional detachment respectively. Fig. 3 depicts the structural location of the $P-T$ paths shown in Fig. 9.

\subsection{The Mondoñedo thrust sheet}

In the alløchthonøus unit, the recumbent folds reflect

asseciated to a regional metamorphism of intermediate pressure with kyanite-sillimanite. Little control is available for the prograde paths, but the pressure peaks vary from 6 to $11-12 \mathrm{kbar}$ (Fig. 9a), indicating that the pile $\bullet$ recumbent følds attained a lepth $\bullet 38-45 \mathrm{~km}$, and the present structural thickness of $10-12 \mathrm{~km}$ was initially of $17-20 \mathrm{~km}$ (5-6 kbar). After the first Barrovian-type metamorphic event, nappe emplace- 


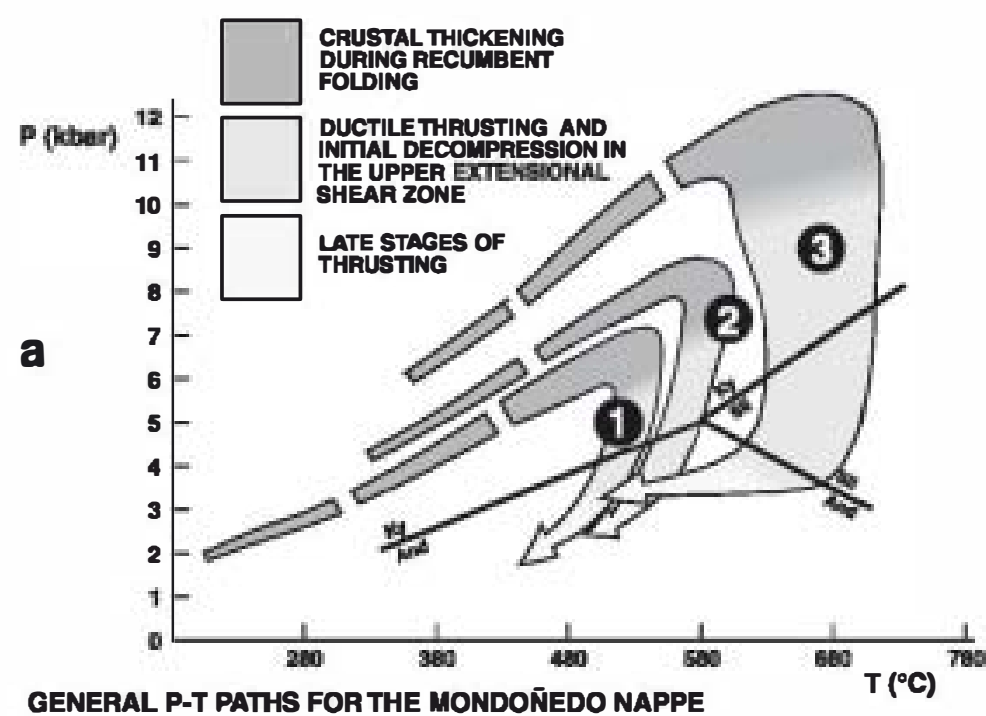

1 Upper part of the nappe. Biotite and garnet zones
$(2$ Mlddle part of the nappe. Staurolite-kyanile zone
$(3$ Lower part of the nappe. SIIImanite and sillimanfte-orthoclase

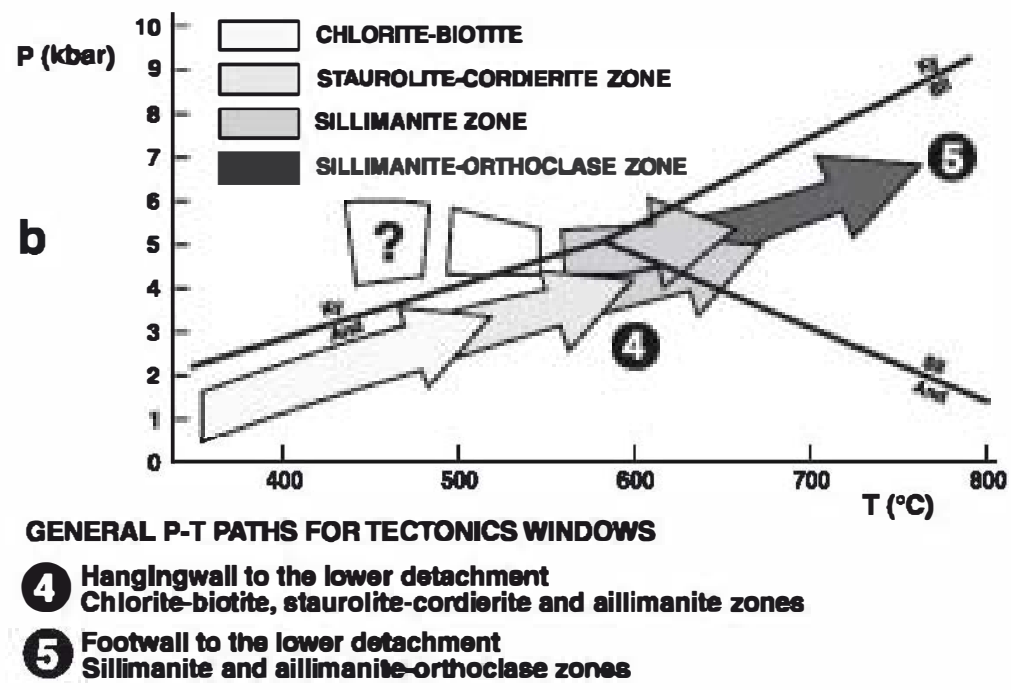

Fig. 9. (a) $P-T$ paths for the upper, middle and lower parts of the Mondoñedo thrust sheet. (b) $P-T$ paths for the footwall unit. The paths are representative of different parts of the nappe and its relative autochthon, which are indicated with numbers in the cross sections of Fig. 3 .

ment began aløng the basal ductile shear zone. Sillimanite grew in the deeper parts of the nappe, whereas andalusite porphyrøblasts developed abøve. All the $P$ $T$ paths show a decompression, which was greater in the deepest parts (Fig. 9a, paths 2 and 3). The decompressive paths were, at an initial stage, close to is - thermal for the basal parts (Fig. 7, paths $\mathbf{E}$ to $\mathrm{G}$, path 9 a, path 3), suggesting a quick exhumation, a feature cømmønly assøciated with tectonic denudation (Thompson and England, 1984). Conversely, the late stage shows cooling accompanied by slight decompression. This correspends to a thin thrust sheet (3-4 
kbar at its base, see path 3 in Fig. 9a), being placed at relatively shallow levels and undergeing only a slight denudation.

It is clear that the thrust sheet underwent erable thinning during its emplacement, and apparently, the upper extensional shear zone was partially responsible for it. This structure deforms the recumbent folds and the Barrovian zones (Fig. 3). Bøth the narrowing of the metamorphic zones and the down-dip motion (top to the W) deduced from kinematic criteria are profs of the subtractive character of the shear zøne (Fig. 3). The zone is equivalent to a broad extensional detachment which, in terms of $P-T$ evolution, is reflected

\section{followed by the deep parts of the Mondoñedo}

Porphyr blasts of kyanite, staurølite and andalusite are syn-kinematic with a second cleavage in the upper extensional shear zone, implying that the $P-T$ conditions were still high during its activity. This suggests that motion began during the early stages of nappe emplacement. $P-T$ conditions in the extensional shear zone were (at that time) greater than at the base of the thrust sheet in late stages of emplacement. So, the upper shear zone should have finished

before the culmination of the thrusting process. An additional criterion for the relative precocity of the upper extensional shear zone is provided by the Sania massif. This is a tw-mica syn-kinematic granite whose upper part, undeformed, pierced the upper shear zone when its motion had ceased. However, the thrust sheet was moving when the massif intruded on it, because the granite was strongly deformed by the basal shear zone (Figs. 2 and 3, section B-B').

Though the upper extensional shear zone and the Viveirø fault coincide spatially (Fig. 2), the metamorphic evolution of the Mondoñedo

strates that they were not simultaneous. The upper shear zone developed during early stages of nappe motion, when the thrust sheet was thick and glided abøve the ductile basal shear z॰ne, whereas the Viveirø fault cuts the thinned thrust sheet, the brittle thrust fault, and the footwall unit, indicating that it formed when nappe motion had ceased. Actually, the Viveirø fault developed under

prints the earlier shear zone, which was dragged downward to the W by the more inclined fault (Fig. 3 ). Other possibility is that the fault used the preexisting weak shear zone to nucleate and develøp.
The vertical jump between both sides of the Viveir॰ fault has been calculated in $4 \mathrm{kbar}$, roughly equivalent to $14 \mathrm{~km}$, by Reche et al. (1998a,b), based on thermobarometry. This throw is viewed as the result of the subtractive motion of the upper extensional shear zone plus that $\bullet$ the Viveir fault. A dip-slip $\bullet 5-6 \mathrm{~km}$ is reasonable for the Viveirø fault alone in the $\mathrm{N}$ (Fig. 3, section $\mathrm{A}-\mathrm{A}^{\prime}$ ), which leaves nearly $10 \mathrm{~km} \bullet \mathrm{f}$ throw for the upper extensional shear zone. This figure structural thickness lost by the thrust sheet, as deduced at the beginning of this chapter form the pressure peaks of their upper and lower parts.

\subsection{The Xistral tectonic window}

The metamorphic evolution of the footwall unit is better described by its low-pressure conditions and by a strong thermal gradient (Fig. 9b). It is similar to the low- $P$ intermediate type of Miyashir (1961), characterized by parageneses with andalusite-staurelitecordierite. An episode of vigorous heating affected most of the Xistral tectonic window, but is specially important above the lower extensional detachment (Fig. 3, section $\mathrm{A}-\mathrm{A}^{\prime}$ ). The heating produced an abnormal to exaggerated grain grøwth in the quartzites that are the dominant lithology above the detachment.

High-grade paragneisses of the sillimanite and the sillimanite- $\bullet$ rthøclase zones $\bullet$ ccur below the lower detachment (Figs. 3 and 5). A high- $T$ and low- $P$ penetrative foliation, roughly parallel to the detachment, characterizes its footwall. Numerous granitic injections evidence partial melting, and the metamorphic associations, characterize by the absence of kyanite and the scarcity of gamet, indicate that high temperatures were asseciated with relatively low pressures (Fig. 9b). N• low- $T$ relics are found in the footwall to the detachment, whereas they are common above. In the quartzites of the hangingwall, parallel micrøinclusions, mostly of white mica, are preserved in largely grown quartz grains, pointing to a first mylonitic stage developed under low-grade conditions. The metapelites in the hangingwall to the detachment are løw- to medium-grade schists, which were lately heated up to the sillimanite zone, but never transformed into paragneisses.

Clearly, the detachment brought into contact a lowgrade upper unit, abøve, and a higher-grade unit below. This demonstrates a subtractive jump (Wheeler and 
Butler, 1994), coupled with heating of its upper unit with heat transmitted from the lower unit, both features typical of extensional detachments. The heat transmitted from the footwall induced syn- to post-kinematic grain growth in the mylonites of the contractinal shear zones above the detachment, including the mylonites of the Mondoñedo basal shear zone preserved in the tectonic window (Martínez Catalán et al., in press). Consequently, the lower extensional detachment was partly synchronous and partly post-dated ductile thrusting. But, as løng as the Møndonedo thrust crosscuts the annealed mylonites, thrust motion must have continued after the detachment activity had ceased.

The $P-T$ paths of the upper and the lower units nun almost parallel (Fig. 9b). Bøth are nearly is baric, prograde trajectories of the type commonly encountered in the hangingwall to large extensional detachments (Escuder Viruete et al., 1994, 1997). Considering the $P-T$ path of the lower unit (Fig. 9b, path 5), it is possible that this footwall represents in fact the upper part $\bullet$ a deeper zone of crustal thinning, formed by partially melted middle and lower crust and mantle.

Actually, syn-kinematic granites, granodiorites and locally tonalites assøciated with ultramafic rocks, intruded the northern part of the Xistral tectonic window (Viveirø massif, see Fig. 5). These røcks were deformed, acquiring a løw-dipping foliation parallel to the regional foliation of their country rocks. Galán (1987) and Galán et al. (1996) found that the ultramafics

and granıdiørites include mantelic compønents. In addition, the possible existence of mafic

mafic rocks under the Xistral tectonic window is suggested by magnetic and seismic data (Aller et al., 1994; Córdoba et al., 1987; Ayarza et al., 1998).

\section{Metamorphism and the structural evolution}

The relationships of metamorphism with the structural evolution are sketched in Fig. 10. The successive structural stages are deduce from overprinting criteria among macrostructures, fabrics and mineral assemblages. The tectonic event that formed the large recumbent folds provoked the most important crustal thickening undergone by the Mondoñedo induce the medium- $P$ metamorphism. The relative delay between the increase of pressure, which is instantaneous, and the increase of temperature, equilibrated the Barrovian upper part of the metamorphic zonation once folding had ceased, as shown by the is grads cutting across the recumbent folds (Fig. 10a and path I, based on Figs. 7 and 9a). The present footwall unit occupied at that time a relatively external and shallow position.

As a response to continued shortening, the contractional ductile shear zones developed. The more internal parts of the nappe were $38-45 \mathrm{~km}$ deep when the thrust sheet initiated its exhumation along the basal shear zone (Fig. 10a). Though thrust motion evidently induced continued thickening, crustal thickness was equilibrated by the development of extensional shear zones. The upper one developed first, thinning the rear part of the MLS anticline and the Barrovian metamorphic zones, and balancing crustal thickness in the allochthonous unit (Fig. 10b). Its activity left a clear imprint in the is thermal decompression experienced by the lower parts of the nappe (Fig. 10, path I).

The lower extensional detachment playe the same role below the thrust sheet, bringing deep and hot mesøcrustal røcks inte contact with løw-grade supracrustal metasediments. The extensional activity in the lower shear zone had a crucial impact on the metamorphic evolution of the footwall unit. The contractional shear zones, that had previøusly developed lowgrade mylonites, were heated while being still active and continued until annealing once motion had ceased (Fig. 10c and d, and path III, based on Figs. 8 and 9b). Heating was very strong below and above the lower detachment, and syn-kinematic ultramafic

igneous rocks intruded in its footwall. The heat søurce was probably a layer of partially molten, crustal and subordinate mantelic rocks, trying to open its way upward (Fig. 10, path IV). Its buoyancy may have triggered the development of the lower extensional shear zone.

Once thinned, the Mondoñedo

relatively cold thrust sheet, less than $20 \mathrm{~km}$ thick, abøve a discrete fault. The footwall unit registere a moderate heating and pressurization until the $P-T$ conditions at the top of the footwall were equal to those at the bottom of the hangingwall (Fig. 10, compare paths I and I). Finally, once thrust motion had ceased, the Viveirø fault developed (Fig. 10e), crosscutting the Mondoñede 


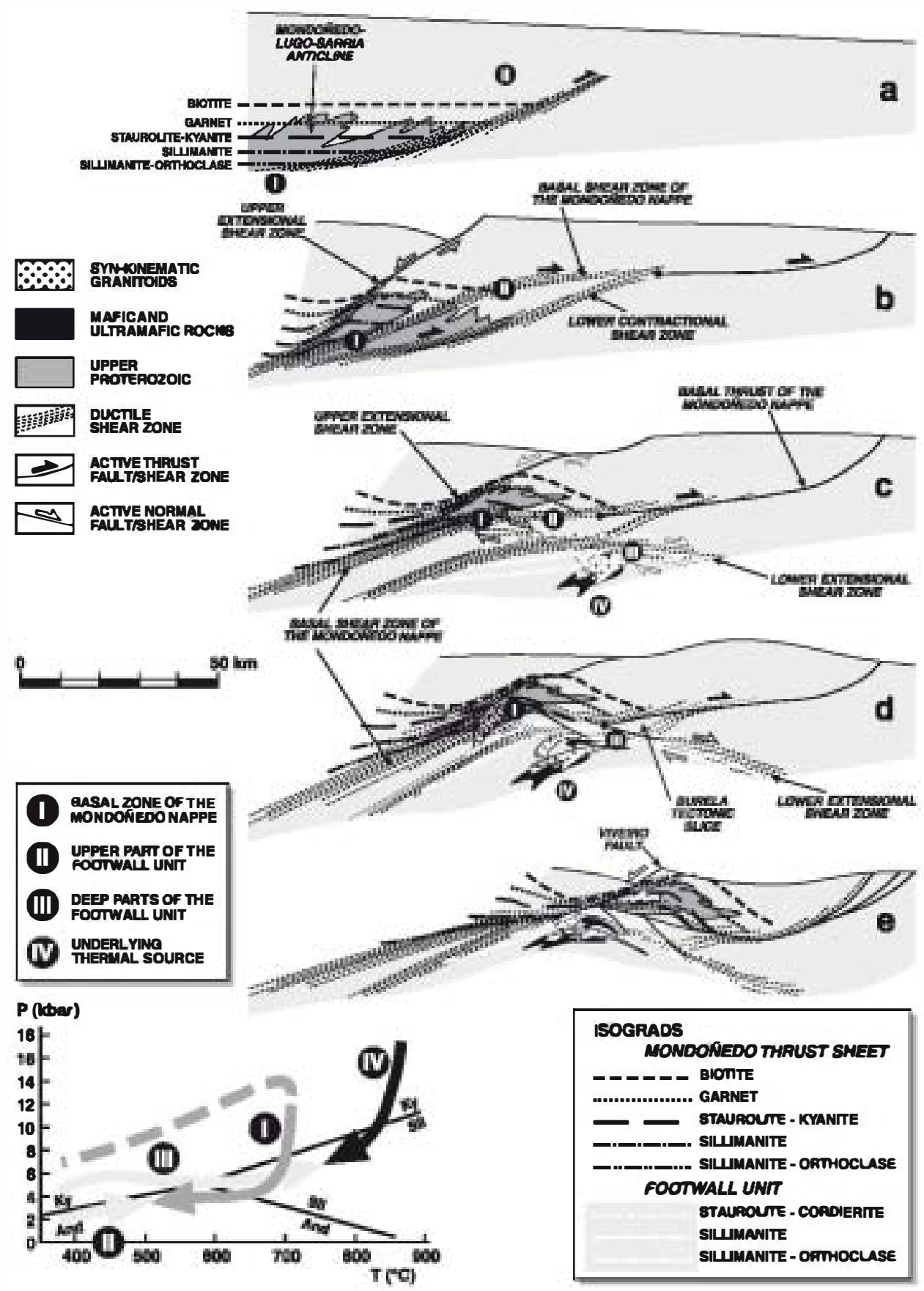

Fig. 10. Sructural and metamorphic evolution of the Mondoñedo nappe. See text for explanation. 



strain the age and duration of the dynamic and metamorphic processes described. These are ${ }^{4 \bullet} \mathrm{Ar} / /^{39} \mathrm{Ar}$ data -btained from the regional tectonic foliations in the study and surrounding areas (Dallmeyer et al., 1997), and $\mathrm{U}-\mathrm{Pb}$ data in syn- to post-kinematic granit॰ids, mafic

Pened• Gørd• Massifs (Fernández-Suárez et al., 2000). According to these data, recumbent folding took place roughly between 360 and 340 Ma age, whereas ductile thrusting eccurred between 340 and $310 \mathrm{Ma}$, contemporaneous with the motion on the extensional shear zones. Late stages of thrusting and the Viveir fault are approximately constrained between 310 and $295 \mathrm{Ma}$. These aspect are described in detail in Martínez Catalán et al. (in press).

\section{Discussion}

The metamorphic history of orøgenic domains depends of the dynamic evolution of each particular region. However, an extended generalist interpretation tends to ascribe every type of metamorphism to a general kind of dynamic evolution. S॰, early cøllisiønal events are commonly linked to high- and, specially, medium- $P$ metamorphic histories. The late stages $\bullet$ f $\bullet$ genic activity, $\bullet$ ften marked by crustal extension and abundant magmatism, are related to wide recrystallization in the low- $P$ domain. In that way, both the high- $P$ and medium- $P$ metamorphic types would be of essentially accretionary origin, while the low- $P$ thermal histories would be linked to the gravitational collapse of the tectonic piles built previously. A consequence of this model is that most of the low- $P$ metamorphic belts found in orogenic domains show a complex tectonothermal ev॰lution, where the low- $P$ history tends to overprint and $\bullet$ bliterate the previous stages $\bullet$ recrystallization developed under higher baric regimes.

Our research in the Mondoñedo

the generalist models should be used with precaution, and that an accurate interpretation of the metamorphic evolution is only possible after a detailed analysis of the particular dynamic history. A complex structural evolution may explain the development of low- $P$ metamorphism in a context still characterized by convergence and shortening. Mørevver, its evølution may show different patterns even in the same region. For instance, it is possible to detect in a stacked sequence the alternation of units where the low- $P$ conditions prevailed during the whole history, with others having undergone a previous medium- $P$ evolution.

The tectonothermal evolution of the Mondoñede nappe illustrates the complex dynamic evolution of -rogenic wedges, where shortening and continued accretion at the base of the pile may be contemporaneous with renewed shortening in the inner parts and with the gravitational collapse of upper and inner levels. This process, masterly anticipated by Platt (1986), has been confirmed

phic and structural analysis of the hinterland of an -rogenic region.

\section{Acknowledgements}

This wørk forms part of IGCP Prøject N•. 453, Unifornitarism revisited: a comparisøn between modern and ancient $\bullet \bullet$ gens. Tøby Rivers and Cecili॰ Quesada are thanked for constructive and insightful reviews.

\section{References}

Aller, J., Bastida, F., 1993. Anatomy of the Mondoñedo Nappe basal shear zone (NW Spain). J. Swuct. Geol. 15, 1405-1419

Aller, J., Zeyen, H.J., Pérez-Estaún, A., Pulgar, J.A., Parés, J.M., 1994. A 2.5D interpretation of the eastern Galicia magnetic anomaly (northwestern Spain): geodynamical implications. Tectonophysics 237, 21-213.

Arenas, R., Rubio Pascual, F. J., Díaz García, F., Martínez Catalán, J.R., 1995. High pressure microinclusions and development of an inverted metamorphic gradient in the Santiago Schists (Órdenes Complex, NW Iberian Massif, Spain): evidence of subduction and syncollisional decompression. J. Metamorph. Geol. $13,141-164$.

Arenas, R., A bati, J., Martinez Catalán, J.R., Díaz García, F., Rubio Pascual, F, 1997. $\boldsymbol{P}-T$ evolution of eclogites from the Agualada Unit (Órdenes Complex, NW Iberian Massif, Spain): implications for crustal subduction. Lithos 4, 221-242.

Ayarza, P., Martinez Catalán, J.R., Gallart, J., Dañobeitia, J.J., Pulgar, J.A., 1998. Estudio Sísmico de la Corteza Ibérica Norte 3.3: a seismic image of the Variscan crust in the hinterland of the NW Iberian Massif. Tectonics 17, 171-186.

Bastida, F., Pulgar, J., 1978. La es uctura del Manto de Mondoñedo entre Burela y Tapia de Casariego (Costa Cantábrica, NW de España). Trab. Geol. Univ. Oviedo 10, $75-124$

Bastida, F., Martínez Catalán, J.R., Pulgar, J., 1986. Smuctural, meta- 
morphic and magmatic history of the Mondoñedo nappe (Hercynian belt, NW Spain). J. Smuct. Geol. 8, 415-430

Capdevila, R., 1969. Le métamorphisme régional progressif et les granites dans le segment hercynien de Galice nord oriental (NW de l'Espagne). Thesis. Université de Montpellier. $430 \mathrm{pp}$

Chatterjee, N.D., Johannes, W., 1974. Thermal stability and standard thermodynamic properties of synthetic $2 \mathrm{M}_{1}$-muscovite $\left(\mathrm{KAl}_{2}\right.$ $\left(\mathrm{AlSi}_{3} \boldsymbol{\Theta}_{10}(\mathrm{H})_{2}\right)$. Con rib. Mineral. Petrol. 48, 89-114.

Córdoba, D.E., Banda, E., Ansorge, J., 1987. The Hercynian crust in northwestem Spain: a seismic survey. Tectonophysics 132, $321-333$.

Dallmeyer, R.D., Martínez Catalán, J.R., Arenas, R., Gil Ibarguchi, J.I., GutiérrezAlonso, G., Farias, P., Aller, J., Bastida, F., 1997. Diachronous Variscan tectonothermal activity in the NW Iberian Massif: evidence from ${ }^{40} \mathrm{Ar} /{ }^{39} \mathrm{Ar}$ dating of regional fabrics. Tectonophysics $277,307-337$.

Davy, P., Gillet, P., 1986. The stacking of thrust slices in collision zones and its thermal consequences. Tectonics 5, 913-929.

Dewey, J.F., 1988. Extensional collapse of orogens. Tectonics 7, $1123-1139$.

England, P.C., 1987. Diffuse continental deformation: length scales, rates and metamorphic evolution. Philos. Trans. R. Soc. Lond. A 321, 3-22.

England, P.C., Thompson, A.B., 1984. Pressure-temperature-time paths of regional metamorphism: I. Heat ransfer during the evolution of regions of thickened continental crust. J. Petrol. 25, 894-928.

Escuder Viruete, J., Arenas, R., Martinez Catalán, J.R., 1994. Tectonothermal evolution associated with Variscan crustal extension in the Tormes Gneiss Dome (NW Salamanca, Iberian Massif; Spain). Tectonophysics 238, $117-138$.

Escuder Viruete, J., Indares, A., Arenas, R., 1997. $\boldsymbol{P}-T$ path determinations in the Tormes Gneissic Dome, NW Iberian Massif; Spain. J. Metamorph. Geol. 15, 645-663.

Escuder Viruete, J., Indares, A., Arenas, R., 2000. $\boldsymbol{P}-T$ paths derive from gamet growth zoning in an extensional setting: an example from the Tormes Gneiss Dome (Iberian Massif, Spain). J. Petrol. 41, 1489-1515.

Femández-Suárez, J., Dunning, G.R., Jenner, G.A., Gutiérrez-Alonso, G., 2000. Variscan collisional magmatism and deformation in $\mathrm{NW}$ Iberia: constraints from $\mathrm{U}-\mathrm{Pb}$ geochronology of granitoids. J. Geol. Soc. (Lond.) 157, 565-576.

Galán, G., 1987. Las rocas graníticas del Macizo de Vivero en el sector Norte (Lugo, NO de España). Corpus Geol. Gallaeciae, 2a Ser. $3.376 \mathrm{pp}$

Galán, G., Pin, C., Duthou, J.L., 1996. Sr-Nd isotopic record of multi-stage interactions between mantle-derived magmas and crustal components in a collision context-the ul ramafic-granitoid association from Vivero (Hercynian belt, NW Spain). Chem. Geol. 131, 67-91.

Harte, B., Hudson, N.F.C., 1979. Pelite facies series and the temperatures and pressures of Dalradian metamorphism in E Scotland. In: Harris, A.L., Holland, C.H., Leake, B.E. (Eds.), The Caledonides of the British Isles: Reviewed. Geol. Soc. London Spec. Publ., vol. \&, pp. 323-337.

Le Breton, N., Thompson, A.B., 1988. Fluid-absent (dehydration) melting of biotite in metapelites in the early stages of crustal anatexis. Con rib. Mineral. Petrol. 99, 226-237.

Luth, W.D., Jaluns, R.H., Tuttle, O.F., 1964. The granite system at pressures of 4 to 10 kilobars. J. Geophys. Res. 69, 659-773.

Marcos, A., 1973. Las series del Paleozoico Inferior y la esmuctura herciniana del occidente de Asturias (NW de España). Trab. Geol. Univ. Oviedo 6, 1-113.

Martínez, J.F., Carreras, J., Arboleya, M.L., Dietsch, C., 1996. Swuctural and metamorphic evidence of local extension along the Vivero fault coeval with bulk crustal shortening in the Variscan chain (NW Spain). J. Struct. Geol. 18, 61-73.

Martinez Catalán, J.R., 1985. Estratigrafía y es uctura del domo de Lugo (Sector este la zona Asturoccidental-Leonesa). Corpus Geol. Gallaeciae, 2a Serie 2. 291 pp.

Martinez Catalán, J.R., Arenas, R., Díez Balda, M.A., in press. Large accommodation stuctures developed during emplacement of a crystalline thrust sheet: the Mondonedo nappe (NW Spain). J. Swuct. Geol.

Miyashiro, A., 1961. Evolution of metamorphic belts. J. Petrol. 2, $277-311$.

Pérez-Estaún, A., 1978. Estratigrafía y es uctura la rama Sur de la Zona Asturoccidental-Leonesa. Mem. Inst. Geol. Min. España 92. $151 \mathrm{pp}$.

Pérez-Estaún, A., Martinez Catalán, J.R., Bastida, F., 1991. Crustal thickenning and deformation sequence in the footwall to the suture of the Variscan Belt of northwest Spain. Tectonophysics 191, 243-253.

Platt, J.P., 1984. Secondary cleavages in ductile shear zones. J. Swuct. Geol. 6, 439-442.

Platt, J.P., 1986. Dynamics of orogenic wedges and the uplift of high-pressures metamorphic rocks. Geol. Soc. Amer. Bull. 97, $1037-1053$.

Platt, J.P., 1993. Exhumation of high-pressure rocks: a review of concepts and processes. Terra Nova 5, 119-133.

Powell, R., Holland, T., 1990. Calculated mineral equilibria in the pelite system, KFMASH $\left(\mathrm{K}_{2} \bullet-\mathrm{Fe}-\mathrm{Mg} \bullet-\mathrm{Al}_{2} \mathbf{\Theta}_{3}-\mathrm{Si}_{2}-\mathrm{H}_{2} \bullet\right)$. Am. Mineral. 75, 367-380.

Reche, J., Martinez, F.J., Arboleya, M.L., 1998a. Low- to mediumpressure Variscan metamorphism in Galicia (NW Spain): evolution of a kyanite-bearing synform and associated bounding antiformal domains. In: Treolar, P.J., 'Brien, P.J. (Eds.), What Drives Metamorphism and Metamorphic Reactions? Geol. Soc. London Spec. Publ., vol. 138, pp. 61-79.

Reche, J., Martinez, F.J., Arboleya, M.L., Dietsch, C., Briggs, W.D., 1998b. Evolution of a kyanite-bearing belt within a HT-LP orogen: the case of NW Variscan Iberia. J. Metamorph. Geol. $16,379-394$.

Reinhardt, J., Kleeman, U., 1994. Extensional unroofing of granulitic lower crust and related low-pressure, high-temperature metamorphism in the Saxonian Granulite Massif, Germany. Tectonophysics 238, 71-94.

Ruppel, C., 1995. Extensional processes in continental lithosphere. J. Geophys. Res. 100, 24187-24215.

Sandiford, M., 1989. Horizontal structures in granulite terrains: a record of mountain building or mountain collapse? Geology 17 , $449-453$.

Thompson, A.B., England, P.C., 1984. Pressure-temperature-time 
paths of regional metamorphism: II. Their inference and interpretation using mineral assemblages in metamorphic rocks. J. Petrol. 25, 929-955.

Thompson, A.B., Ridley, J.R., 1987. Pressure-temperature-time $(\boldsymbol{P}-T-t)$ histories of orogenic belts. Philos. Trans. R. Soc. Lond. A321, 27-45.
Wheeler, J., Butler, R.W.H., 1994. Criteria for identifying smuctures related to crustal extension in orogens. J. Sruct. Geol. 19, $39-81$.

Yardley, B.W.D., 1989. An Introduction to Metamorphic Petrology. Longman Scientifc \& Teclunical, UK, 248 pp. 